\title{
Pseudo-intellectualism and Melancholy.The Poetics of Black Bile in Lucian's Lexiphanes
}

\section{Pseudo-intelectualismo y melancolía. La poética de la bilis negra en el Lexífanes de Luciano}

\author{
George Kazantzidis ${ }^{1}$ \\ University of Patras (Grecia)
}

Recibido: 09-03-19

Aprobado: 22-03-19

\begin{abstract}
In Lucian's highly competitive and exhibitionist world, hyper-Atticism, the (ab)use of recondite, archaic words for the sake of impression, has become a sort of plague. In this article, I discuss how Lexiphanes focuses precisely on the literal and metaphorical associations of hyper-Atticism as a disease, by paying particular attention on the medical verdict - articulated in the text by Lucian's authorial double, Lycinus - that the dialogue's eponymous character suffers from melancholia. Rather than constitute a passing reference to the colloquial vocabulary of insanity, melancholia, I argue, helps Lucian forcefully assimilate the accumulation of pretentious words to the raving of the insane, a non-sensical blabbering that is void of meaning. At the same time, Lucian aims also to expose the presence of melancholy in the cultural and medical idiom of his time as a disease that typically affects 'great spirits', people of exceptional intelligence. By calling Lexiphanes 'melancholic', Lucian scolds Lexiphanes' pretentiousness both as a hyper-Atticist and, no less importantly, as a pseudo-intellectual who is shaping his public image, temperamentally and physiognomically, as a genius whose atrabilious constitution entitles him to act and speak in strange ways.
\end{abstract}

Key-words: melancholia, hyper-Atticism, pseudo-intellectualism, obscurity/void of meaning, fashioning of public image/ impersonation.

\footnotetext{
${ }^{1}$ (gkazantzidis@upatras.gr) Assistant Professor of Latin Literature at the University of Patras, Greece. He graduated from Aristotle University of Thessaloniki and obtained his DPhil from the University of Oxford, with a thesis on Melancholy in Hellenistic and Latin Poetry. His interests lie at the crossroads between medicine and literature in antiquity, with a special focus on the history of mental illness and the emotions. He is currently finishing his monograph on disease in Lucretius' De rerum natura and looks forward to moving on to his next book project, provisionally entitled: 'Greek and Roman Paradoxography: Medicine, Horror, the Sublime'.
}

Araucaria. Revista Iberoamericana de Filosofia, Politica, Humanidades y Relaciones Internacionales, año $21, \mathrm{n}^{\circ} 41$. Primer semestre de 2019. Pp. 289-310. ISSN 1575-6823 e-ISSN 2340-2199 doi: 10.12795/araucaria.2019.i41.14 


\section{Resumen}

En el mundo altamente competitivo y exhibicionista de Luciano, el hiper-aticismo, el (ab)uso de palabras recónditas y arcaicas a fin de impactar deviene en una especie de plaga. En este artículo discuto cómo el Lexífanes se centra precisamente en las asociaciones literales y metafóricas del hiperaticismo como una enfermedad, prestando especial atención al dictamen médico -articulado en el texto por el doble del autor, Licinio-, según el cual el personaje epónimo del diálogo sufre de melancolía. En lugar de constituir una referencia de pasada al vocabulario coloquial de la locura, la melancolía -sostengo- ayuda a Luciano a asimilar a la fuerza la acumulación de palabras pretenciosas para el desvarío de un loco, un parloteo no sensitivo carente de significado. Al mismo tiempo, Luciano también pretende exponer la presencia de la melancolía en el lenguaje cultural y médico de su época como una enfermedad que de manera especial afecta a los "grandes espíritus", a las personas de inteligencia excepcional. Al llamar a Lexífanes 'melancólico', Luciano reprende la pretensión de Lexiphanes a la vez como hiper-aticista y, no menos importante, como pseudointelectual que está configurando su imagen pública, temperamental y fisiológicamente, como un genio cuya atrabiliaria conformación le permite actuar y hablar en modos extraños.

Palabras-clave: melancolía, hiper-aticismo, pseudo-intelectualismo, oscuridad/vacío de significado, diseño de imagen pública/suplantación.

\section{Introduction}

Lucian's Lexiphanes constitutes a vitriolic attack against those who abuse language for the sake of impression. ${ }^{2}$ The dialogue's eponymous character boasts of having composed a literary work, a 'Symposium', in imitation/rivalry of Plato. ${ }^{3}$ When Lycinus, Lucian's authorial double, invites him to recite a part of it, we soon find out that the promised text is desperately incoherent, mixing curious words and ideas to no clear end. Instead of the Platonic setting that one would have expected, as well as a clearly focused discussion on a philosophical subject, what we get are nauseating catalogues of food combined with loosely plotted scenes moving from the bath-house to the dinner table, and containing characters whose posture borders on the ludicrous and the obscene. So deep

\footnotetext{
${ }^{2}$ And in this respect, it is very similar to Lucian's Rhetorum Praeceptor ('A Professor of Public Speaking'). Some have argued that both works target the figure of Pollux, the famous grammarian and sophist of the second century CE; see Anderson 1976: 68-9.

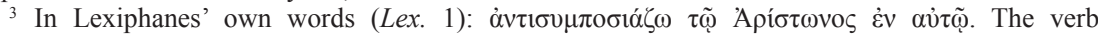
$\dot{\alpha} \nu \tau \imath \sigma \nu \mu \pi 0 \sigma \iota \alpha ́ \zeta \varepsilon \imath v$ suggests imitation but also a certain degree of competition. Lexiphanes clearly writes under Plato's shadow but not without a certain 'anxiety of influence', in Bloomian terms.
} 
is Lycinus' aversion towards what he has been unwittingly exposed to that he suddenly stops Lexiphanes from going any further, claiming that clearly he is in need of a doctor. When this doctor (Sopolis) 4 materializes in the scene, the diagnosis (formulated first by Lycinus and then passed to the professional for proper treatment) is that Lexiphanes, literally a 'word-flaunter', suffers from melancholia. It is from this condition that he needs to be 'purged', puking out and evacuating all those troublesome words which, just like noxious fluids in excess, have thrown his body and mind in turmoil (Lex. 16):

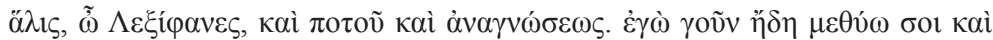

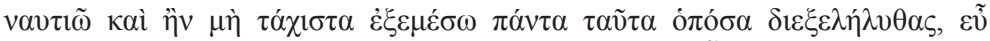

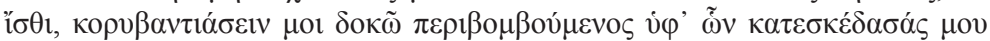

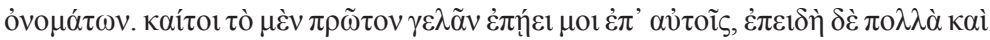

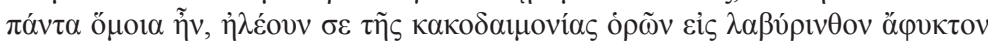

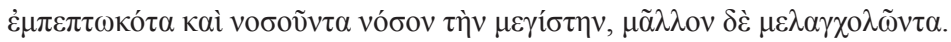

Enough, Lexiphanes, both of the drinking-party and of the reading. I am already half-seas-over and squeamish, and if I do not very soon jettison all this gallimaufry of yours, depend upon it, I expect to go raving crazy with the roaring in my ears from the words with which you have showered me. At first I was inclined to laugh at it all, but when it turned out to be such a quantity and all of a sort, I pitied you for your hard luck, seeing that you had fallen into a labyrinthine maze from which there was no escaping and were afflicted with the most serious of all illnesses - I mean, were as mad as a hatter. ${ }^{5}$

Lycinus confesses that he is genuinely puzzled by the spectacle he has been watching. At first sight, Lexiphanes' ridiculous performance gives the

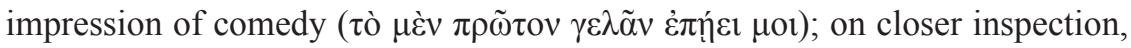
it turns out to be a tragedy ( $\hat{\eta}\langle\dot{\varepsilon}$ ov $\sigma \varepsilon$ ). Integral to this tragic script is that Lexiphanes seems 'lost in a labyrinthine maze' from which there is no hope of escaping-a self-delusional situation which contains all those symptoms usually associated with melancholia. ${ }^{7}$

Calling someone 'melancholic' is not uncommon in colloquial contexts of ridicule and comic abuse. Already in Aristophanes, it is employed as a slang way of saying that someone has 'gone insane'/ is 'out of his mind', without

${ }^{4}$ As Baldwin 1973: 36-40 behind 'Sopolis' we can detect several allusions to Galen.

5 Translations for Lucian's Lexiphanes are taken from Harmon 1936.

${ }^{6}$ For the trope of the maze as a metaphor for madness in cases where literary creation gets out of control, see Strauss 1998: 92.

7 Sickness is a standard trope for characterizing (with the intent to devalue) the sophists of Lucian's time. Gleason 1995: xviii draws attention on 'the physical weaknesses of the second century's leading literary figures: Aristides on the Greek side, laid low by epilepsy; Fronto on the Latin side, at death's door with gout; and last, born without testicles, "that Gaul, highly learned in both languages, whose appearance his enemy Polemo thus described in his Physiognomy: 'forehead taut, mouth relaxed, skinny neck, fat calves, fleshy feet... all limbs and joints without vigor, lax and loose.'”. Cf. Bowersock 1969: 75. 
necessarily implying that a medical condition is actually involved. ${ }^{8}$ The aim of this article is to explore a bit further Lucian's passage quoted above. As I will argue, rather than constitute a passing, colloquial reference to the disease, the author's mention of melancholy flags a sustained and informed engagement with its medical background. ${ }^{9}$ This medical background is activated throughout and helps to shape a considerable part of the dialogue in at least two significant ways: on the one hand, the pathology of melancholy (a condition that is ultimately traced down to a surplus of fluid in the body, a 'hyperbole' ${ }^{10}$ of black bile) is manifest across the text by becoming closely intertwined with the notion of excess from which the hyper-Atticist Lexiphanes is suffering. More to the point, just like black bile is said to 'cast its shadow', literally and metaphorically, over the mind and to disrupt communication between the affected subject and the external environment, ${ }^{11}$ so does hyper-Atticism, a figurative sickness of language, obscure meaning by turning Lexiphanes into a user of recondite words which are no different from the babbling and raving of the insane. On the other hand, and on a more general, socio-cultural level, melancholy presents for Lucian a fitting subject in order to explore issues of posture and deception in the profoundly antagonistic and exhibitionist world of the second Sophistic. ${ }^{12}$ For Lucian's world, imitation is a serious issue, ${ }^{13}$ an inspired way of turning an eye to the past and creating something original out of it. But imitation, by its very nature, can also be subject to distortion, exaggeration and misuse; it can be employed as a tool for presenting someone as something that he is not. Melancholy, as we shall have the opportunity to see, is one of those peculiar diseases that can be faked precisely to this effect. Given black bile's long-established association with notions of creativity and superior intelligence ([Arist.] Problems 30.1), ${ }^{14}$ a melancholic posture - manifesting

${ }^{8}$ See e.g. Ar. Av. 14; Ec. 251; Pl. 12, with Padel 1995: 48.

9 On Lucian's Lexiphanes as a medically informed text, see Martin (forthcoming).

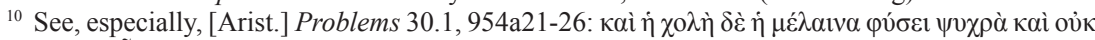

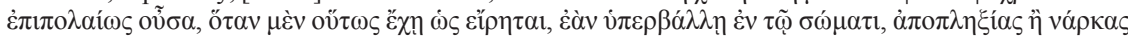

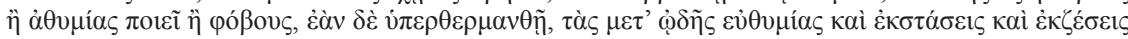
$\dot{\varepsilon} \lambda \kappa \tilde{\omega} \nu \kappa \alpha i ̀ ~ \alpha ̋ \lambda \lambda \alpha \tau$ oเ $\alpha \tilde{v} \tau \alpha$. For the link between hyper-Atticism and the notion of excess (of lacking a $\mu \varepsilon \dot{\tau} \rho \circ v)$, see e.g. Philostratus, Vit. Apoll. 1.17, with Kim 2017: 44.

11 See, especially, Galen, De locis affectis 3.10, where we are told that as external darkness makes almost everybody experience fear, in the same way the color of the black humour induces fear when its darkness throws a shadow over the area of the thought. The literal and metaphorical associations of black bile blend in this passage and become almost indistinguishable. For a discussion, see Clark and Lynn Rose 2013: 62-3.

12 For self-presentation and self-fashioning in the Second Sophistic, see Gleason 1995. For the cultural associations of melancholy in the same period, see Pearcy 1984. And for Lucian's interest in melancholy, see Swain 2008: 119.

13 See Whitmarsh 2001.

14 The text, dating back to the late $4^{\text {th }} /$ early $3^{\text {rd }}$ century BCE assumes an intricate link between a 'melancholic constitution' (a sort of natural excess of black bile in the body) and exceptional creativity in poetry, philosophy and the arts. See van der Eijk 2005: 139-68. For its reception during the first century CE and its crucial contribution to the shaping of the image of 'melancholic Democritus' 
itself either with manic outbursts or long fits of dejection and thoughtful silence - could have easily provided the means to shape the persona of a troubled genius. Clothing and physical appearance, as has been amply demonstrated in scholarship, were integral to sophistic performance. As Lucian's 'Professor of Rhetoric' shamelessly admits: 'first of all, you must take care of your style and the attractiveness of your dress; then pick fifteen or (at the most) twenty Attic words, and practice them cautiously'. ${ }^{15}$ There is no reason to believe that this crafted fashioning of outward appearance was limited to dressing; it must surely have applied also to one's physiognomy and 'cultivated' temperament. Lucian, as I will discuss, is aware of the ways in which mental illness is mimicked and turns into a show, with Lexiphanes presenting - among other things - an acerbic attack against posers and 'melancholic fakes' of this kind.

\section{Meaning and nonsense}

In a testimony transmitted by Diogenes Laertius (which repeats a claim originally made by Theophrastus), Heraclitus, the obscure philosopher par excellence, is said to have suffered from melancholy (Vitae Philosophorum 9.6):

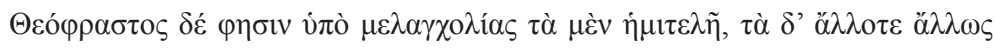

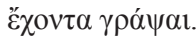

Theophrastus claims that it was because of Heraclitus' melancholy that some parts of his work remained half-finished, while other parts are in contradiction with each other.

Diogenes' reference to melancholy aims to explain the reason why some of Heraclitus' work was left unfinished while what has survived thrives in contradictions. It is crucial to note that Diogenes does not speak at this point of a 'void' of meaning; its intention, in other words, is not to expose Heraclitus as a non-sensical philosopher (as especially the phrase $\tau \dot{\alpha} \delta$ ' $\ddot{\alpha} \lambda \lambda \mathrm{o} \varepsilon \varepsilon \ddot{\alpha} \lambda \lambda \omega \varsigma$ appears to suggest). Quite on the contrary, it places fragmentation and the way in which language resists a straightforward interpretation at the centre of a brilliant, genius-like philosophy ${ }^{16}$ whose meaning is elusive and requires effort in order to be reconstructed. What we have in the case of Heraclitus - similar to the distinctive feature of a naturally melancholic constitution - is an excess

in the ps.-Hippocratic Letters, see Kazantzidis 2018. Finally, for the dominant presence of the ps.Aristotelian Problem in $1^{\text {st }}$ century CE medical thought, see van der Eijk 2008.

${ }^{15}$ Rhetorum Praeceptor 16; with Whitmarsh 2005: 26-7.

${ }^{16}$ For further discussion of Diogenes' reference to the 'melancholic' Heraclitus and its connection with the ps.-Aristotelian tradition of the 'melancholic genius', see Kazantzidis 2018: 78, with n.128. 
of meaning manifesting itself in contradictions which imply polysemy and plurality, and which effectively balance the philosopher's 'half-finished' words.

Lexiphanes' 'Symposium' takes on meaning - or such at least seems to be its author's intention - precisely because of its obscurity ( $\varphi \alpha$ ív $\omega$, shaping etymologically the eponymous character's name, is not so much about 'revealing' as it is about 'displaying' and confusing). Obscurity in Lexiphanes' case works its way into the text at two levels: first, by means of the excessive use of 'weird' and 'twisted' words, some of them made-up by the author and others retrieved from strange sources: ${ }^{17}$ second, but no less importantly, at the level of content: while Lycinus has been promised a 'Symposium' that would somehow rival/imitate that of Plato's, it is not late before we find out that what we get is not a philosophical debate but, rather, a light-hearted and playful banquet whose characters import random, personal stories unrelated to each other. Whether Lexiphanes' 'Symposium' was intended to culminate at some point into a serious philosophical discussion remains unknown. Disgusted by what he hears, Lycinus suddenly interrupts the aspiring writer/philosopher, saying that he clearly needs to see a doctor (Lexiphanes' text thus combines obscurity with enforced fragmentation).

Lucian's Lexiphanes, I submit, could be read as a sophisticated comment on the dual nature of melancholy which in the previous medical and philosophical tradition has come to acquire the double status of a pathological condition, on the one hand, and that of a disease which is closely associated with an inspired state of mind, on the other. ${ }^{18}$ The text takes as its starting point a character who is posing as a 'genius' but is soon revealed to descend into a state of pure insanity. Indeed, if some degree of coherence is to be found in Lexiphanes' narrative, it is mainly by means of reading it as the raving of a patient whose repetitiveness, lack of clear scope, strange words and obscenities read as 'symptoms' of a mind in turmoil. What looks and sounds non-sensical in his case can be integrated, in other words, into a coherent clinical picture revolving around mental illness and black bile more specifically.

Lexiphanes' most distinctive symptom is his delirious talk. This is how Lycinus introduces him to Sopolis, the doctor in the dialogue (Lex. 18):

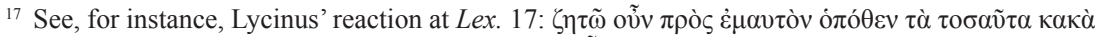

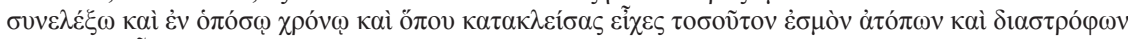

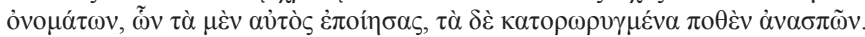

${ }_{18}$ Both wisdom and pure madness can be accommodated within the conceptual space of melancholy, in a curiously symbiotic relationship. As I argue elsewhere with reference to [Arist.] Problems 30.1, "what distinguishes a natural melancholic from those who are simply affected by an occasional excess of black bile is the fact that he stands above others and acquires unique intellectual characteristics. This state of wisdom, however-indicated as бopía in the title of the ps.-Aristotelian

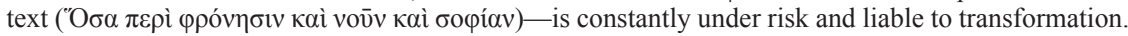
The reason, as the author explains, is that black bile is "anomalous" by nature and can change its temperature suddenly, from hot to cold and vice versa, thereby losing its optimum state and giving rise to disease (954a14-b10; 955a29-32)' (Kazantzidis 2018: 71). 


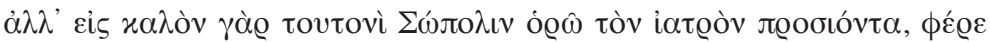

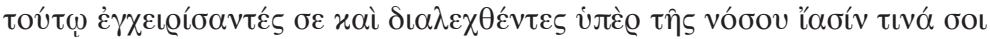

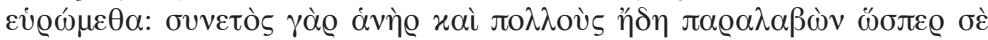

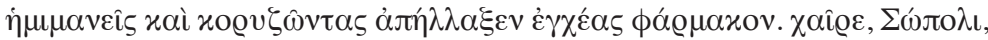

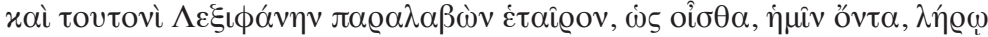

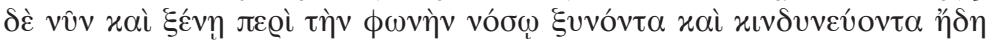

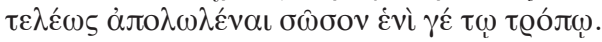

But what luck! here I see Sopolis the physician drawing near. Come now, suppose we put you in his hands, have a consultation with him about your complaint, and find some cure for you. The man is clever, and often before now, taking charge of people like yourself, half crazed and full of drivel, he has relieved them with his doses of medicine. - Good-day to you, Sopolis. Do take charge of Lexiphanes here, who is my friend, as you know, and at present has on him a nonsensical, outlandish distemper affecting his speech which is likely to be the death of him outright. Do save him in one way or another.

Lexiphanes' illness is simultaneously recognizable and strange. From what Lycinus tells Sopolis, it seems to approximate some sort of mild insanity

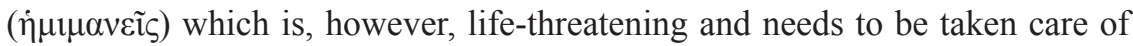
immediately. At the same time, the fact that its symptomatology is specifically

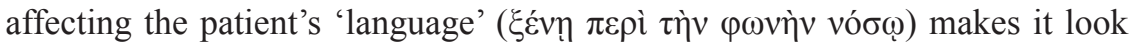
somewhat bizarre. ${ }^{19}$ As Lycinus explains later in the dialogue, Lexiphanes is carried away by fanciful verbs and nouns and uses them without even knowing what they mean. Rather than formulating his thoughts first and dressing them with an appropriate language, the patient opts instead for words which sound impressive, at the expense of a concrete meaning. ${ }^{20}$ The result is a sort of diction where the link between signifier and signified has been violated and where content recedes to the background giving its place to what ultimately manifests itself as a series of inane sounds. This vocal aberration ( $\left.\lambda \eta \eta^{\prime} \omega\right)$ is no different from the incomprehensible, self-isolating language in which a madman talks.

$\Lambda \tilde{\eta} \rho \circ \varsigma, \lambda \eta ́ \rho \eta \sigma \iota \varsigma, \lambda \eta \rho \varepsilon \tilde{v}, \pi \alpha \rho \alpha \lambda \eta ́ \rho \eta \sigma \iota \varsigma$ commonly appear in medical texts in order to describe 'delirious' talk, usually induced by fever or drunkenness. For instance, in [Hipp.] Epid. 1.13, Case 3, a patient by the name of Herophon is seized by a fit of acute fever and insomnia, displaying on the fifth day

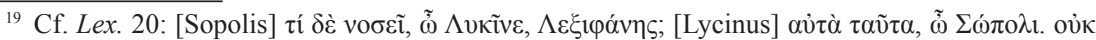

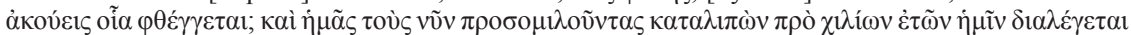

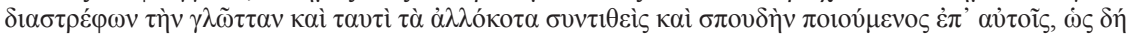

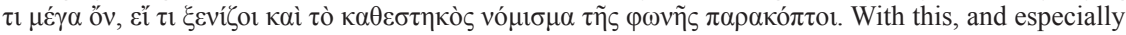

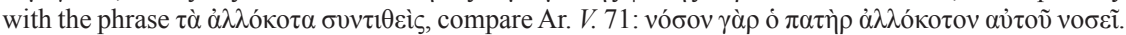
For the hypothesis that behind Lexiphanes' semi-Platonic, semi-comic 'Symposium' lies a scene from Old Comedy, see Storey 2003: 38.

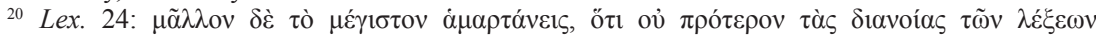

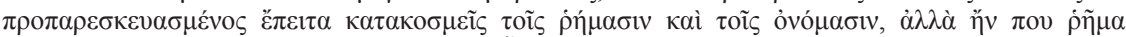

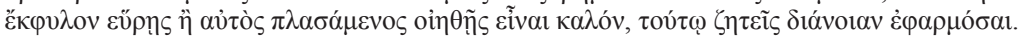

Araucaria. Revista Iberoamericana de Filosofia, Política, Humanidades y Relaciones Internacionales, año $21, \mathrm{n}^{\circ} 41$. Primer semestre de 2019. Pp. 289-310. ISSN 1575-6823 e-ISSN 2340-2199 doi: 10.12795/araucaria.2019.i41.14 


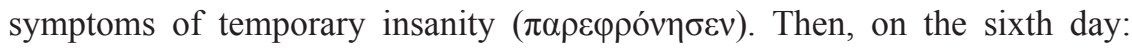

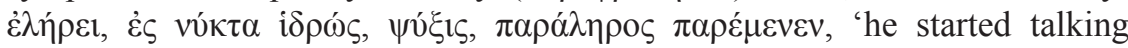
nonsense; he was sweaty during the night and was seized by shudders; delirious talk persisted' ${ }^{21}$ Indeed, so close is the connection between $\lambda \eta \rho \varepsilon \tilde{i} v / \varphi \lambda v \alpha \rho \varepsilon \tilde{v} v$

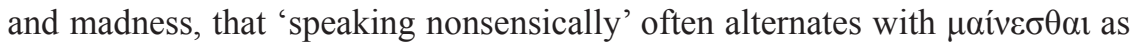
a conceptual synonym. Take, for instance, the following prognosis ([Hipp.] De morbis 2.22): 'If, looking up and speaking he is in his senses and does not

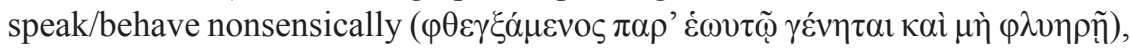
he will lie down drowsy this day, but on the next will become healthy. But if,

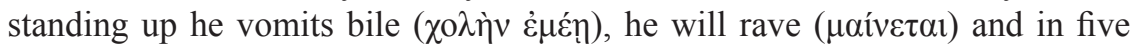
days die indeed, if he does not sleep'. ${ }^{22}$ Bile, vomit and the risk of the patient's life all appear as details in the clinical picture which Lycinus is building for Lexiphanes. ${ }^{23}$ Whether directly indebted to (earlier or contemporary) medical sources or indirectly drawing on a widespread, colloquial idiom of mental illness, Lucian's intention remains that of presenting the hyper-Atticist at play on the verge of mental and biological collapse.

But what does $\lambda \eta \rho \varepsilon \tilde{v} v$ mean exactly? What kind of language qualifies as 'non-sensical'? Although medical authors make heavy use of the term, we seem to lack instances of a clear-cut, detailed description of the actual content of $\lambda \tilde{\eta} \rho \varsigma^{24}$ Several hypotheses have been put forward. Some have argued that $\lambda \tilde{\eta} \rho \circ \varsigma$ seems 'to involve something akin to the babbling that takes place while a patient is asleep'. ${ }^{25}$ Random phonemes combine with animal noises and snippets of actual speech of no discernible value. As Webster puts it in a discussion of the formula $\lambda$ ó $\gamma$ or $\pi$ o $\lambda \lambda$ oí used for mentally affected patients in the Hippocratic Corpus, when the physicians 'classify 'words' as a diagnostically valuable pathology, they functionally strip the patient's voice of all linguistic content and instead reduce the emissions of the mouth to a raw material being excreted. Purged of any possible verbal meaning, the voice becomes a crude emission, a substance to be scrutinized and examined'. ${ }^{26}$ Reducing speech to an evacuation of sounds which are devoid of meaning and materialize as fluids excreted from the body is crucial also for Lucian's understanding of Lexiphanes' condition (Lex. 21):

${ }^{21}$ For $\lambda \eta \rho \varepsilon \tilde{i}$, see also [Hipp.] Epid. 7.1.56, 1.3.13(1).15, 3.1.1.3, 3.2.5.8, 7.1.25.8, 7.1.25.13, 7.1.25.20-3, 7.1.26.16, 7.1.109.5, 5.1.80.1.

${ }^{22}$ Translation in Kidd 2014: 27, who observes: "it is clear that "speaking or behaving nonsensically"

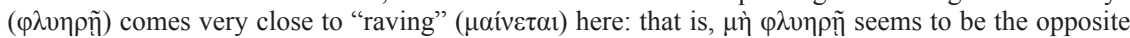

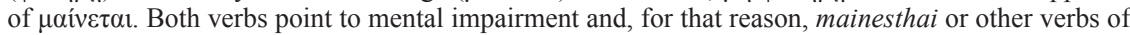
madness often appear together with phluarein or other verbs of nonsense' (pp.27-8).

${ }^{23}$ For bile, see $\mu \varepsilon \lambda \alpha \gamma \chi \alpha \lambda \tilde{\omega} \nu \tau \alpha$ (Lex. 16) and Lex. 20 (the one speaking is Sopolis, the doctor):

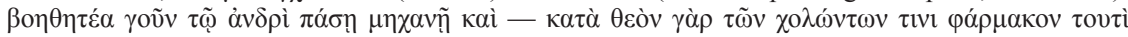

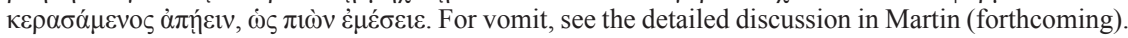

${ }^{24}$ See Kidd 2014: 32.

25 Webster 2016: 188 .

26 Webster 2016: 188.

Araucaria. Revista Iberoamericana de Filosofía, Política, Humanidades y Relaciones Internacionales, año $21, \mathrm{n}^{\circ} 41$ Primer semestre de 2019. Pp. 289-310. ISSN 1575-6823 e-ISSN 2340-2199 doi: 10.12795/araucaria.2019.i41.14 


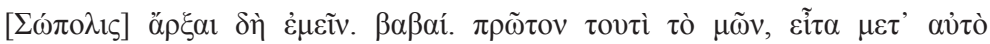

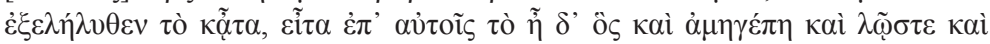

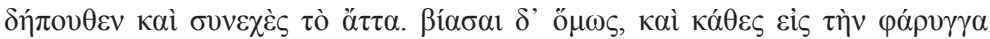

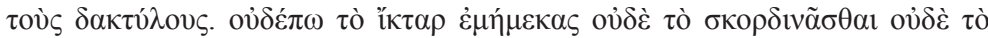

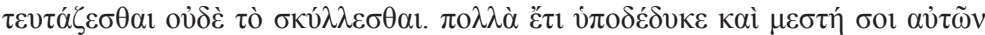

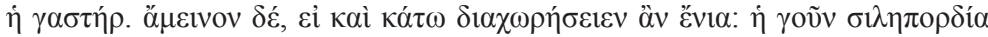

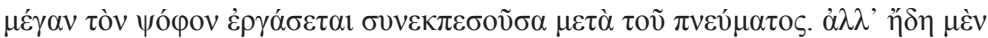

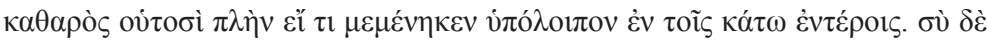

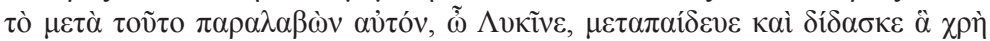
$\lambda \varepsilon ́ \gamma \varepsilon ı$.

[Sopolis] Begin now to lighten yourself. Aha! First, this "prithee" then after it "eftsoons" has come up; then on their heels his "quoth he" and " in some wise," and " fair sir," and " in sooth," and his incessant " sundry." Make an effort, however; put your fingers down your throat. You have not yet given up "instanter" or "pandiculation" or " divagation " or "spoliation." Many things still lurk in hiding and your inwards are full of them. It would be better if some should take the opposite course. Anyhow, "vilipendency" will make a great racket when it comes tumbling out on the wings of the wind. Well, this man is now purged, unless something has remained behind in his lower intestines. It is for you next, Lycinus, to take him on, mending his education and teaching him what to say.

As Sopolis provides Lexiphanes with an emetic in order to help him puke out the archaic diction which is ailing him, the latter is suddenly heard to emit a series of phrases, nouns, adverbs and particles in no particular sequence. In the text cited above, which describes this process of lexical vomit, I highlighted some of Lexiphanes' evacuated matter, words reduced into sounds, which lose substance as they have no meaningful connection with each other. Since the scene is reported by Sopolis, we have to imagine that the patient is literally gurgling out words and is producing the following sound:

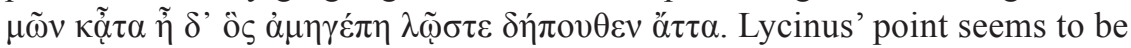
that the 'Symposium' from which Lexiphanes has been reciting to him so far is not essentially different from the disgusting stuff which is now coming out from the latter's mouth. ${ }^{27}$ At the same time, the evacuation of words which are literally forced out from the patient's stomach could function as a neat comment of what a delirious talk amounts to: namely, a series of sounds which are not cognitively shaped but become reduced to pure bodily matter, no different from vomit, shit, burps and farts. ${ }^{28}$

Indeed there seems to be something inherently 'disgusting' in the way Lexiphanes talks. Before we reach the end of the dialogue, where Sopolis'

\footnotetext{
${ }^{27}$ On the connection between silly talk and vomit, see Worman 2008: 300 .

${ }^{28}$ For the suggestion that some of Lexiphanes' archaic diction could be evacuated from the anus,

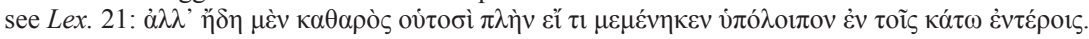


therapeutic intervention induces a vomit of words from the patient, Lycinus, as we have seen, has complained that Lexiphanes' 'nauseating' Symposium

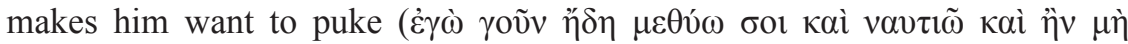

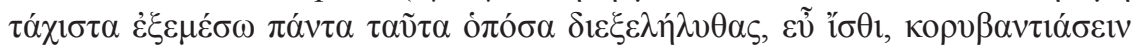
$\mu \mathrm{ol} \delta$ боб()). Expressing aversion in such strong terms towards someone else's literary production can be a strong way of implying one's superior position towards the object that causes disgust; the notion of distaste helps Lycinus, and by implication Lucian, present himself as a connoisseur who simply can't stand the rubbish he has been listening to. This sort of disgust, as Kaster has brilliantly illustrated in his discussion of fastidium in Roman texts, is not activated instinctively and reflexively-it is not the physical aversion which we feel when we become suddenly exposed to a bad smell or taste. On the contrary, it implicates a series of values and judgments, revealing a "pattern of engagement that might be labeled "deliberative and ranking". This reaction is of the kind "that people experience when they have considered at some level of consciousness the relative value or status of two or more things (or people) - including, very often, their own value or status relative to some thing (or person) - and have decided to rank one of those things (or people) so low as to have an aversion to it (or him) '. ${ }^{29}$

But what is it precisely that makes Lexiphanes' way of writing so repulsive? We should start by noting that Lycinus' aversion may be related to both style/ diction and subject-matter. Recondite words combine with distasteful details of content. Consider, for instance, the following, nauseating catalogue of foods which Lexiphanes lists one by one, thinking that the result should impress Lycinus (Lex. 6):

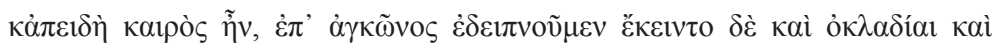

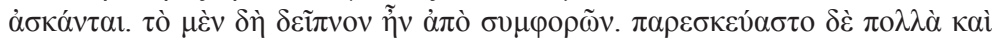

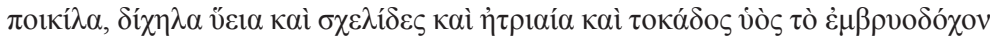

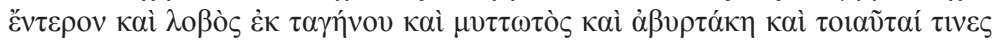

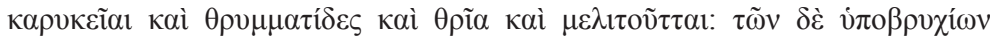

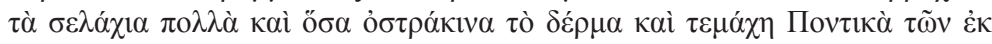

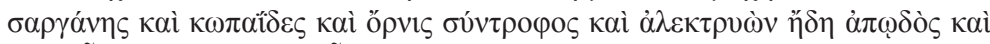

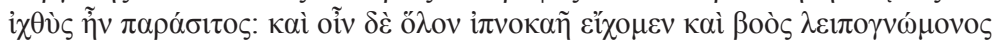

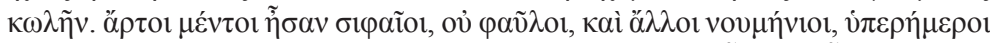

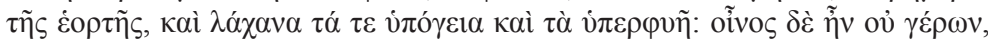

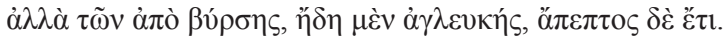

When the time was ripe, we dined on our elbows. Both faldstools and truckles were at hand. The dinner was picked up; many different viands had been made ready, pig's trotters, spareribs, tripe, the caul of a sow that had littered, panned pluck, spoonmeat of cheese and honey, shallot-pickle and other such

${ }^{29}$ Kaster 2005: 105.

Araucaria. Revista Iberoamericana de Filosofia, Política, Humanidades y Relaciones Internacionales, año $21, \mathrm{n}^{\circ} 41$ Primer semestre de 2019. Pp. 289-310. ISSN 1575-6823 e-ISSN 2340-2199 doi: 10.12795/araucaria.2019.i41.14 
condiments, crumpets, stuffed fig-leaves, sweets. Of submarine victuals, too, there were many sorts of selacian, all the ostraceans, cuts of Pontic tunny in hanapers, Copaic lassies, vernacular fowl, muted chanticleers, and an odd fish - the parasite. Yes, and we had a whole sheep barbecued, and the hindquarter of an edentulous ox. Besides, there was bread from Siphae, not bad, and novilunar buns, too late for the fair, as well as vegetables, both underground and over grown. And there was wine, not vetust, but out of a leathern bottle, dry by now but still crude.

There is something very ripe and rotten about some of the foods that

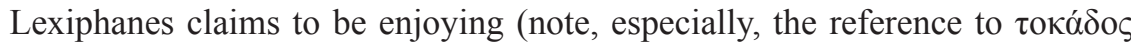

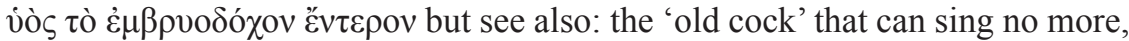

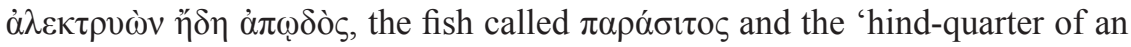

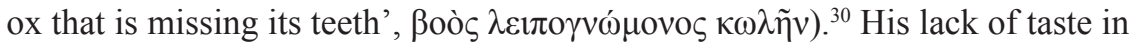
language is thus reflected in a lack of taste for good food. But apart from these disgusting details, what makes the content of Lexiphanes' piece particularly unsettling is its incongruous material. For reasons of space, I will focus here on one specific aspect of the 'Symposium' that looks out of place, namely Lexiphanes' unwarranted emphasis on death, in ways that reveal a frivolous handling of the subject and which in the end convey a really bad sense of taste on the author's part.

Two scenes are of particular interest. In the first of them, found at the very start of Lexiphanes' 'Symposium', the speaker describes himself being invited by a certain Callicles to the bathhouse. Lexiphanes responds that he will gladly join him; it's been ages since he had his last bath-yet another 'filthy' detail contributing to the text's distasteful tempo (Lex. 2):

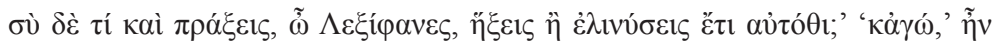

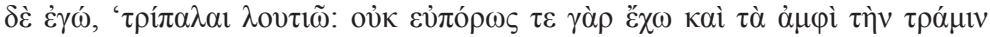

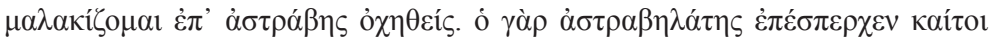

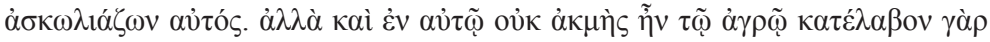

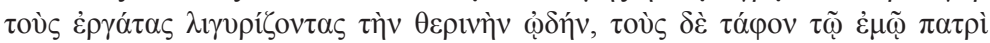

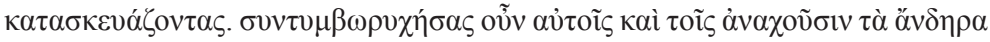

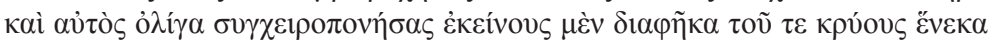

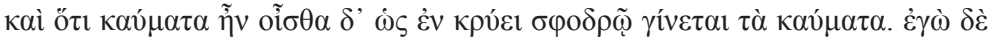

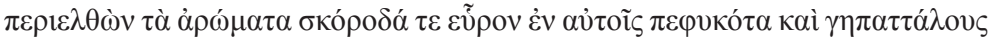

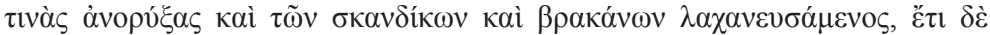

${ }^{30}$ There is no doubt that several of these dishes were considered to be extravagant delicacies, and Lexiphanes mentions them precisely as such. But the sheer amount and accumulation of foodstuff may as easily have evoked disgust (naturally, for someone like Lycinus who is not fond of pompous words, excessive luxury in food would be equally repulsive). Disgust in Petronius' Satyricon is usually discussed alongside the unsettling implication that his dinner contains allusions to cannibalism; see Lateiner 2017: 203-5 and Rimell 2002: 53. Compare Lucian's ßoò...$\kappa \omega \lambda \tilde{\eta} v$ : the noun $\kappa \omega \lambda \tilde{\eta}$ (here with the meaning of the thighbone with the flesh on it) is used by Aristophanes to describe a man's penis, e.g. in $N u b .989,1019$.

Araucaria. Revista Iberoamericana de Filosofia, Politica, Humanidades y Relaciones Internacionales, año $21, \mathrm{n}^{\circ} 41$. Primer semestre de 2019. Pp. 289-310. ISSN 1575-6823 e-ISSN 2340-2199 doi: 10.12795/araucaria.2019.i41.14 


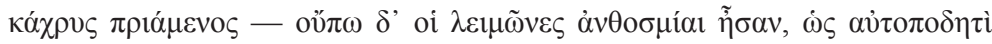

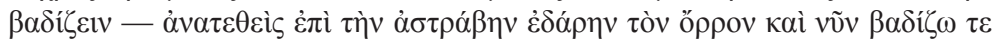

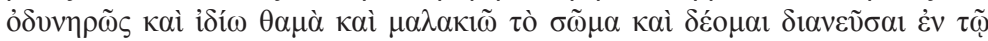

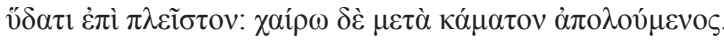

[Callicles] "Shall you come, or tarry yet a while hereabouts ?" [Lexiphanes] "I too," said I, "am yearning to ablute these ages past, for I am ill-conditioned, susceptible behind from riding pillion on a mule. The muleteer kept me going, though he himself was jigging it hot-foot. But even in the country I was not unassiduous, for I found the yokels caroling the harvest-home; some of them, too, were preparing a grave for my father. After I had assisted them in the engraving and for a brief space shared the handiwork of the dikers, I dispersed them on account of the cold and because they were getting burned (in severe cold, you know, burning ensues). For myself, I got about the simples, found prickmadam growing among them, exhumed sundry radishes, garnered chervils and potherbs, and bought groats. But the meads were not yet redolent enough for travelling by shank's mare ; so I mounted the pillion and had my rump excoriated. Now I walk excruciatingly, I perspire amain, my flesh is very weak, and I want to play about in the water no end. I delight in the prospect of dissolution after toil.

The pink elephant in the passage is the grave of Lexiphanes' father. Lexiphanes mentions it as a passing, insignificant detail, ${ }^{31}$ squeezed between his emphatic complaint for his irritated buttocks and his care-free roaming through the countryside in search for culinary herbs. Death is uncomfortably intruding into the narrative, and the effect is further accentuated by Lexiphanes' careless use of language: the participle employed to describe the building of the tomb, $\sigma v v \tau v \mu \beta \omega \rho v \chi \eta \dot{\sigma} \sigma \alpha \varsigma$, is the standard word applied to grave-digging (a slip of the tongue, which the speaker seems not to be noticing in his attempt to accumulate long, multisyllabic words). Equally intriguing as regards death's insidious presence in the text is Lexiphanes' statement that he is looking

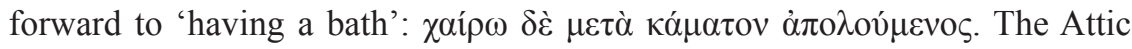
contraction of $\dot{\alpha} \pi \mathrm{o} \lambda \mathrm{ovó} \mu \varepsilon v \mathrm{~s}$ to $\dot{\alpha} \pi \mathrm{\alpha} \mathrm{\lambda ov} \mu \varepsilon v \mathrm{~s}$ produces identity of form with the future of $\dot{\alpha} \pi \hat{\prime} \lambda \lambda v \mu \alpha 1$. The prospect of bathing (and then of dining) turns unwittingly into an anticipation of dying.

This blurring of boundaries between a life-celebrating event - such as a symposium was principally meant to be - and death may have something to do with the tradition of the 'funeral banquet', $\pi \varepsilon p i \delta \varepsilon 1 \pi v o v$, with which Lucian is clearly toying elsewhere in his work. But as with everything else, Lexiphanes gets it all wrong. A funeral banquet was an occasion during which eulogies were delivered by those present for the deceased and songs were performed in his honour. According to Artemidorus (Oneirocritica 5.82.7), the assumption

${ }^{31}$ It is not clarified whether his father has actually died or the tomb is prepared in the event that he dies. The point is deliberately obscured.

Araucaria. Revista Iberoamericana de Filosofía, Política, Humanidades y Relaciones Internacionales, año $21, \mathrm{n}^{\circ} 41$ Primer semestre de 2019. Pp. 289-310. ISSN 1575-6823 e-ISSN 2340-2199 doi: 10.12795/araucaria.2019.141.14 
was that the deceased was still among the dinner-participants and that he was accepted in Hades only after the dinner was completed..$^{32}$ The solemnity of this formal event is downgraded and defused in Lexiphanes' 'Symposium'. Death makes its presence felt, but only to the effect of bringing out the characters' indecency and lowness. As Lexiphanes keeps reciting from his work, we hear of a certain Eudemus who joins the dinner late. When Lexiphanes asks the reason for his late arrival, Eudemus informs the company that an acquaintance of his attempted suicide and he had to save him, hence the delay. This produces a nasty reaction on Lexiphanes' part (Lex. 11-12):

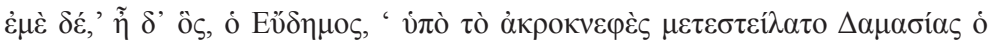

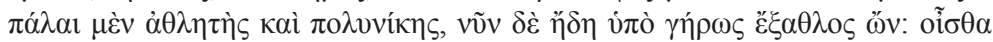

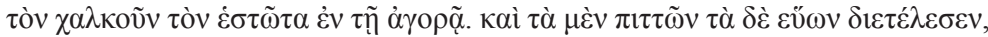

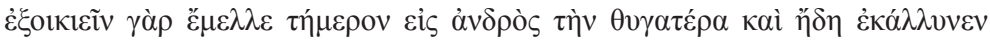

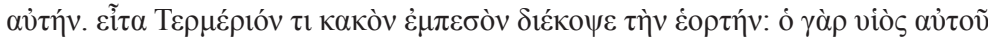

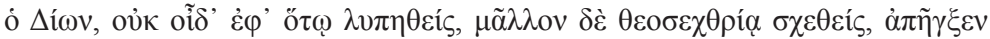

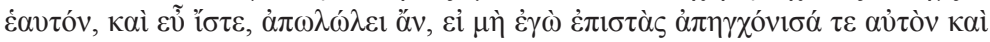

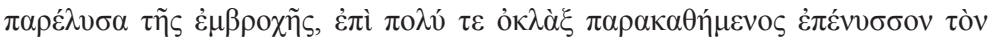

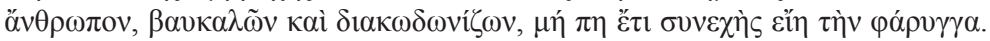

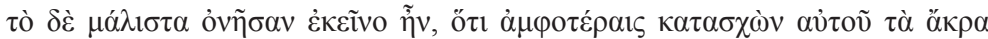

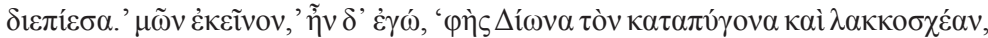

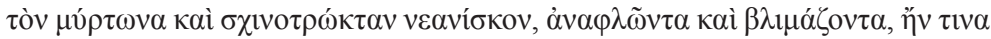

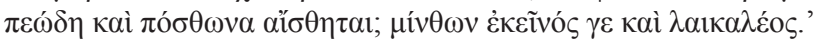

"I," quoth Eudemus, " was summoned as it grew crepuscular by Damasias the quondam athlete and champion, now out of the lists for eld - the brazen image, you know, in the square. He was hard at it a-plucking and a-singeing, for he intended to marry off his daughter today and was busking her. Then a Termerian misadventure befell that cut short the gala day. Distraught over I know not what, or more likely overtaken by divine detestation, his son Dion hung himself, and, depend upon it, he would have been undone if I had not been there to slip the noose and relieve him of his coil. Squatting on hunkers beside him for a long time, I jobbed him, titillating and sounding him lest perchance his windpipe still hang together. But what helped most was that I confined his extremes with both hands and applied pressure." " Prithee," quoth I, " dost mean that notable Dion, the slack-pursed libertine, the toothpickchewing aesthete, who strouts and gropes if ever he sees anyone that is well hung? He is a scapegrace and a rutter."

'Lucian's laughter', as Bakhtin famously observes, 'is always abstract, ironical, devoid of true gaiety'. ${ }^{33}$ Life-affirming as it might be in the end, Lucian's mocking of death normally requires a persona who lacks empathy and can be derisive in aggressive and insulting ways. Lexiphanes' unexpected response

${ }^{32}$ See Avramidou 2011: 45-6; Klotz / Oikonomopoulou 2011: 13.

33 Bakhtin 1984: 387. For a thorough discussion of Lucianic laughter, see Halliwell 2008: 429-70. 
to the news of Dion's misfortune could be appropriately set in this context. However, this doesn't make it any less incongruous, especially if we take into account the fact that his homophobic tirade is voiced in the course of what has been advertised at the beginning of the text as a Platonic, sympotic narrativewhich makes us readers expect for a completely different attitude towards

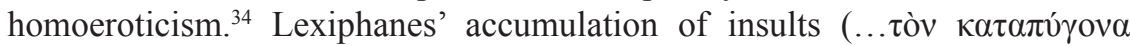

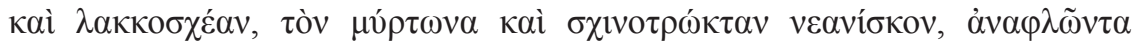

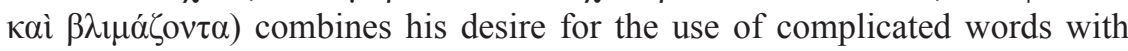
what ultimately amounts to a foul-mouthed and unsettling language. I would venture the hypothesis that the obscene tone of the text at this point may have something to do with Lycinus' subsequent remark concerning Lexiphanes' frail state of mind. In medical texts, the use of foul language is typically a symptom of mentally affected patients. In one occasion, [Hipp.] Epid. 4.15, a delirious young man displays a pathologically aggressive behavior, fighting, jumping and

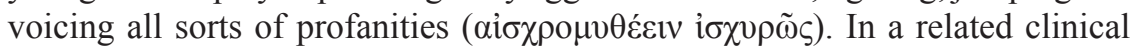
instance, [Hipp.] Epid. 3.17, Case 11, a young woman - who among else suffers from fits of fear and sadness ( $\varphi$ óßoı, $\delta v \sigma \theta v \mu i ́ \alpha)$, probably a reference to melancholia - lapses into outbreaks of delirium and 'speaks incontinently

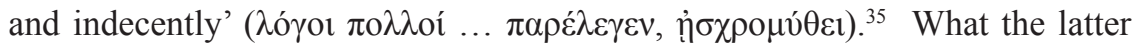
of these medical passages reveals is an intrinsic link between 'talking too much' and losing one's sense of control over what is socially and culturally appropriate and acceptable. When Lycinus suddenly stops Lexiphanes from continuing with his non-sensical speech, declaring him 'insane' and asking for a doctor's help, what he actually sees is a verbal incontinence which is pathologized precisely along these terms, both metaphorically (as a bloated speech in need of a cure $)^{36}$ and literally, as a symptom of an affected mind.

\section{Lexiphanes’ melancholic twist}

But why does Lycinus speak specifically of melancholia? Do we deal here with just another colloquial term for insanity, introduced in the text for the sake of exaggerating Lycinus' aversion towards Lexiphanes' hyper-Attic mumbojumbo? Far from it. Lucian's use of the term, as I will proceed to argue in this section, is deliberate and focused; it aims at poking fun at the long-established notion (going back to [Arist.] Problems 30.1) of the presumable link between genius and melancholy, which in the world of the Second Sophistic seems to

\footnotetext{
${ }^{34}$ For a thorough discussion, see Sheffield 2006.

35 See Gundert 2002: 35 and Thumiger 2017: 362, 386.

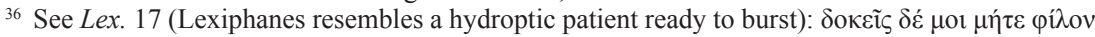

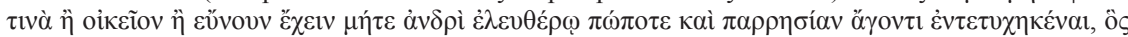

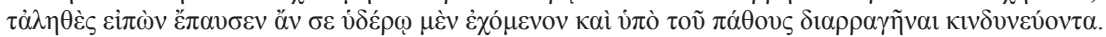


have been rather popular. The following passage by Aulus Gellius will help to provide us with a lead (Noctes Atticae 18.7.1-4): ${ }^{37}$

\begin{abstract}
Domitio, homini docto celebrique in urbe Roma grammatico, cui cognomentum "Insano" factum est, quoniam erat natura intractabilior et morosior, ei Domitio Favorinus noster cum forte apud fanum Carmentis obviam venisset atque ego cum Favorino essem, "quaeso" inquit "te, magister, dicas mihi, num erravi, quod, cum vellem demegorias Latine dicere, "contiones" dixi? dubito quippe et requiro, an veterum eorum, qui electius locuti sunt, pro verbis et oratione dixerit quis "contionem". Tum Domitius voce atque vultu atrociore "nulla" inquit "prorsus bonae salutis spes reliqua est, cum vos quoque, philosophorum inlustrissimi, nihil iam aliud quam verba auctoritatesque verborum cordi habetis. Mittam autem librum tibi, in quo id reperias, quod quaeris ... Cumque digressi essemus, 'non tempestiue' inquit Fauorinus 'hunc hominem accessimus.

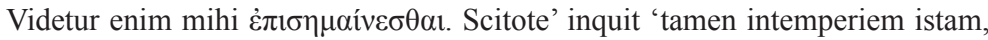
quae $\mu \varepsilon \lambda \alpha \gamma \chi 0 \lambda i \alpha$ dicitur, non paruis nec abiectis ingeniis accidere, $\dot{\alpha} \lambda \lambda \dot{\alpha}$ cĩv $\alpha 1$

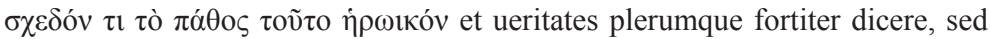

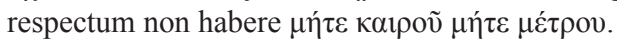

Favorinus' only mistake in the passage cited above is to ask Domitio, a brilliant yet very difficult grammarian, whether contio is a good word for 'public speech' in Latin. Domitio becomes infuriated, disappointed as he is by the degree of Favorinus' pedantry: what has the world come to if even philosophers care about the meaning of individual, petty words? But before abandoning Favorinus, as one would have expected from his initial response, Domitio promises to provide him with an answer-only not now, since the matter is complicated so he will have to send him a book in which a detailed explanation of the word's semantics can be found. After leaving the scene, Favorinus explains Domitio's behavior by saying that the grammarian surely must suffer from melancholy, not a random disease (pathos) but one which only affects 'great spirits' (non parvis ingeniis). This type of people, as he adds, have the tendency to speak the truth boldly, although it needs to be said that they have no sense of measure and appropriate timing (sed respectum non

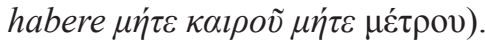

Favorinus clearly alludes here to the ps.-Aristotelian, Problem 30.1 in which it is stated that people of superior intelligence - be it in philosophy, poetry, politics and the arts - have a 'melancholic constitution', a surplus of black bile which, when appropriately conditioned by a balance of hot and cold, allows them to reach the state of a genius. ${ }^{38}$ But behind his apparently

\footnotetext{
${ }^{37}$ On this text, see Holford-Strevens 2003: 150-1 and Howley 2018: 254.

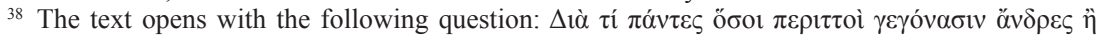

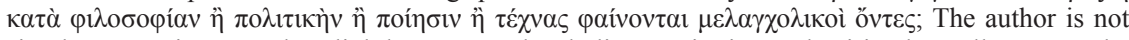
simply suggesting a random link between melancholic constitution and spiritual excellence. By the way the opening question is put (see especially $\pi \alpha ́ v \tau \varepsilon \varsigma$ ), it is implied that a melancholic constitution is 
deferential attitude towards Domitio, we can also detect a great deal of irony. On the one hand, Domitio criticizes Favorinus for spending too much energy on 'obscure' words (glossaria namque colligitis et lexidia) rather than inquiring, as a philosopher should do, into broader and more crucial issues, whereas he, Domitius, proves to be the real philosopher, addressing all those questions which Favorinus neglects: ego enim grammaticus uitae iam atque morum disciplinas quaero. As Keulen aptly observes, 'the reader is' thus 'invited to refute Domitius' own claims to authority, and to unmask him as just as boastful a grammaticus as his other colleagues in the Noctes who mock Gellius' philological inquiries'. ${ }^{39}$ More importantly, when Domitio sends the book eventually (18.7.5ff.) we find out that it thrives in strange words: the grammarian who got so angry over Favorinus' simple inquiry about contio turns out to be himself susceptible to the sort of exhibitionist vocabulary which obscures clarity for the sake of impression and which effectively undercuts any of his claims to moral superiority. ${ }^{40}$

It is only when Domitius' true character is revealed that we can appropriately set Favorinus' reference to melancholy in context. Instead of taking it at face value - namely accept that Favorinus actually believes that genius can be biologically reduced to a surplus of humour in the body - we should start thinking whether his diagnosis is thrown in as an ironic comment for those who assume an angry 'melancholic' posture on the assumption that this fits the profile of a genius. In doing so, we should not fail to notice that Favorinus' (deceptively) respectful claim that melancholy is characteristic of 'great spirits' ( $\mu \varepsilon \lambda \alpha \gamma \chi 0 \lambda i \alpha$ ... non paruis nec abiectis ingeniis accedere) has something in common with Lycinus' reference to the same disease, when diagnosing Lexiphanes:...

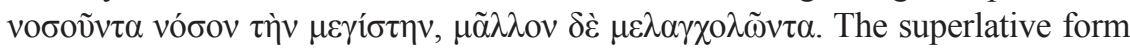
$\mu \varepsilon \gamma \dot{\sigma} \sigma \tau \eta$ can either be translated as 'the most serious of pathological conditions' or be seen, alternatively, as an ironic nod to the assumption that this is reputedly the 'greatest' and most 'magnificent' of all diseases-the only one from which the boastful Lexiphanes could be suffering.

This would not have been the only place where Lucian pokes fun at the notion of melancholic genius and the ways in which such a genius could in theory be impersonated. One need only remember the case of Peregrinus, perhaps the most infamous impostor and self-proclaimed intellectual in Lucian's entire work. This is what we read at the very opening of De morte Peregrini:

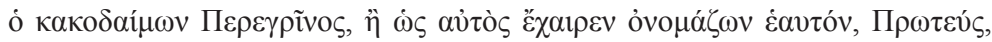

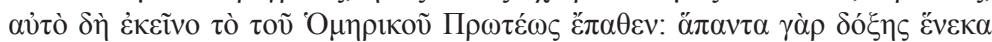

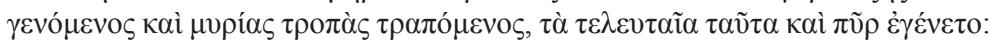

a necessary requirement for someone to excel.

39 Keulen 2009: 139.

${ }^{40}$ For Domitio's exhibition of 'verbal bravura', see Holford-Strevens 2003: 151. 


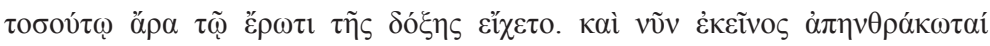

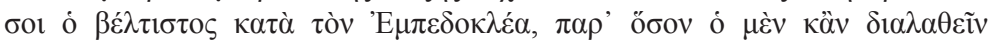

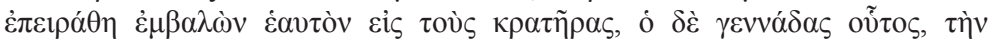

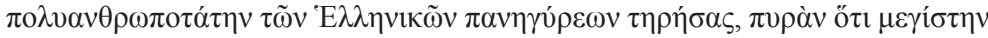

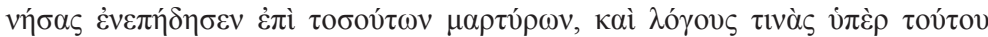

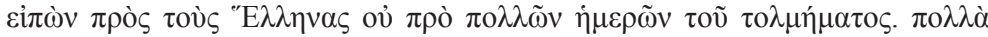

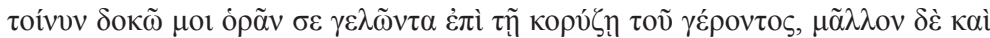

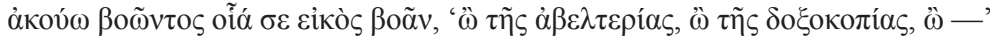

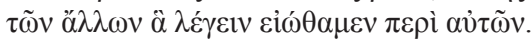

Ill-starred Peregrinus or as he liked to call himself Proteus, has suffered exactly the same fate as the Homeric Proteus. After turning himself into all things for the sake of notoriety and adopting umpteen changes of shape, he has at long last turned into fire: such, it seems, was his passion for fame. And now your fine friend has been burned to a cinder, like Empedocles; except that the latter tried to avoid notice when he threw himself into the crater, whereas this noble fellow waited for the most crowded of the Greek festivals, piled up a most enormous pyre, and jumped into it in front of all those witnesses. He even made a speech about it to the Greeks a few days before his escapade. I seem to picture you convulsed with laughter at the driveling old fool-or rather, I can hear you crying out, as you well might: 'Oh, the stupidity! Oh, the thirst for renown! Oh-', all the other things we tend to say about them. ${ }^{41}$

The resemblance between Peregrinus' suicide by fire and Empedocles' fatal jump into the crater of Aetna ${ }^{42}$ is by no means incidental. When Menippus comes across Empedocles in the Underworld (D. Mort. 6.4), the philosopher explains that he jumped into Aetna 'in a fit of melancholia': [Mغ́vı $\pi \pi \circ \varsigma$ ]

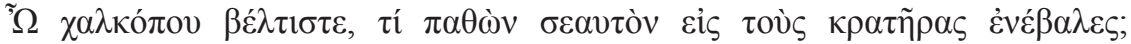

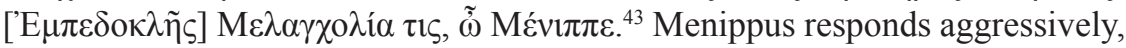
saying that it was nothing of the sort. Rather, it all appears to have happened in

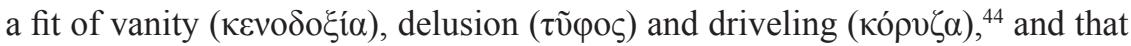
he deserved to be burned to ashes. What is the reason for Menippus' outburst? After all, he seems to agree with Empedocles that the death was the result of insanity. The point here is a delicate one and has not received adequate attention. Considering that in the ps.-Aristotelian Problem 30.1 Empedocles is mentioned among the great melancholic geniuses of the past, ${ }^{45}$ the philosopher's self-

\footnotetext{
${ }^{41}$ Translation in Costa 2006: 74-5; slightly modified at points.

${ }^{42}$ For a magnificently ironic account of Empedocles' suicide, where 'inspired madness' turns out to be intimately linked to pure and common nonsense, see Horace, Ars Poetica 453-76.

${ }^{43}$ For Empedocles' melancholia see also Lucian, Fugitivi 2.

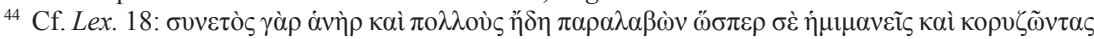

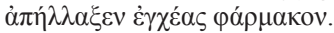

45 [Arist.] Problem 30.1, 953a 10-28: $\Delta$ ì̀ $\tau$ í $\pi \alpha ́ v \tau \varepsilon \varsigma$ ő

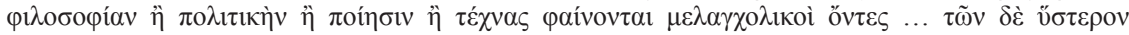

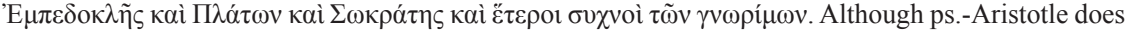
not tell us what it is that qualifies Empedocles as a melancholic it is believed that his appearance in the 
diagnosis in Lucian's text is ultimately a vain and egocentric concession, a sly way of confessing to a form of insanity peculiar to exceptional spirits. The evidence provided by the text suffices to show that in the idiom of Lucian's time melancholia could be abused for the sake of impression: rather than indicate a simple form of illness, it could be exaggerated and even impersonated as long as the underlying assumption was that it came with the package of a troubled yet gifted mind.

\section{Conclusion}

Lucian's aversion towards what may be termed a 'melancholic posture', I submit, can also be traced in Lycinus' mention of melancholy as regards Lexiphanes' condition. Lycinus' intention is not simply to insult Lexiphanes by means of using the colloquial language of insanity but, more specifically, to expose his attitude as that of a pseudo-intellectual who pretends to be something that he is not; in this he succeeds by employing a specialized term, $\mu \varepsilon \lambda \alpha \gamma \chi 0 \lambda \tilde{\omega} \nu \tau \alpha$, associated as much with insanity as with the notion of pretense and disguise. One of the remarkable innovations in [Arist.] Problem 30.1 pertains to the clear-cut distinction between melancholic temperament and melancholic disease: having a natural excess of black bile makes one susceptible to illness but it is conceived, first and foremost, as part of one's nature, a constituent element that can exist independently of any pathological associations (954a12; 954a39-40). Black bile is not simply a pathological cause; it has primarily 'character-affecting' qualities, indicated by the author with the use of the word ethopoion (discussed in detail at 955a29-35). Ëthopoiia, essentially the capacity to assume a mask that is not one's own, lies at the cultural core of the Second Sophistic when it comes to issues of imaginative and imitative invention. I would argue that it is precisely black bile's conception as a humour out of which a 'character' is made as well as the melancholic's innate ability to assume

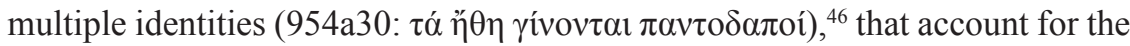
employment of this particular disease as a trope for role-playing. In Lucian's time, there is plenty of evidence to suggest that certain types of mental illness form part of the cultural capital through which one's public image is shaped and debated. Galen's story about Diodorus the grammarian who has epileptic seizures when his mind gets overworked or, before him, Rufus of Ephesus'

text is directly related to his alleged suicide; see Flashar 1962: 719. For a connection between Lucian's melancholic Empedocles and the ps.-Aristotelian tradition, see Swain 2008: 119 n.23.

${ }_{46}$ As the author explains, black bile is a mixture of hot and cold but also 'anomalous' by nature. For instance, it can turn suddenly too hot, making someone cheerful, and then it can become too cold, causing dejection and silence.

Araucaria. Revista Iberoamericana de Filosofía, Política, Humanidades y Relaciones Internacionales, año $21, \mathrm{n}^{\circ} 41$ Primer semestre de 2019. Pp. 289-310. ISSN 1575-6823 e-ISSN 2340-2199 doi: 10.12795/araucaria.2019.i41.14 
claim that too much study and abstract thinking can lead to melancholy ${ }^{47}$ show that disease can occasionally acquire 'positive connotations'. Passing as ill could therefore become a way of establishing one's authority.

In Consonants at Law, another of Lucian's ironic accounts of excessive linguistic purism during the second century CE., sigma protests that rho had struck him on the face, 'owing to melancholy' but was forgiven because of

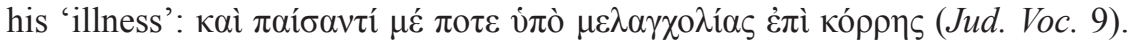

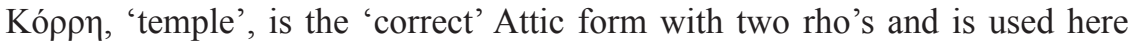
on purpose instead of кópбๆ. As with Lexiphanes' language, hyper-Atticism (in the form of fixating on the reproduction of two similar consonants side by side) raises here the suspicion of melancholy. If anything, this shows that Lycinus' diagnosis for the aspiring Atticist is neither incidental nor without its significance: it is aimed to stress the abuse of words and sounds at the expense of content and, effectively, to expose Lexiphanes' 'melancholic' insanity as a façade that obscures the speaker's real intentions in the same way that his language is meant to be confusing.

${ }^{47}$ For Galen and Rufus, see Mattern 2013: 249 and van der Eijk 2008 respectively. 


\section{Bibliography:}

Anderson, 1976: G. Anderson, Lucian (Leiden, 1976).

Avramidou 2011: A. Avramidou, The Codrus Painter: Iconography and Reception of Athenian Vases in the Age of Pericles (Wisconsin, 2011).

Bakhtin 1984: M. Bakhtin, Rabelais and his World, transl. H. Iswolsky (Indiana, 1984).

Baldwin 1973: B. Baldwin, Studies in Lucian (Toronto, 1973).

Bowersock 1969: G. W. Bowersock, Greek Sophists in the Roman Empire (Oxford, 1969).

Clark / Lynn Rose 2013: P. A. Clark and M. Lynn Rose, Psychiatric Disability in the Galenic Medical Matrix [in C. Laes, C. Goodey, M. Lynn Rose, eds.: Disabilities in Roman Antiquity: Disparate Bodies a capite ad calcem, Leiden 2013], pp. 45-72.

Costa 2006: C. D. N. Costa, Lucian: Selected Dialogues (Oxford, 2006).

Flashar 1962: H. Flashar, Aristoteles: Problemata Physica (Berlin, 1962).

Gleason 1995: M. Gleason, Making Men: Sophists and Self-Presentation in Ancient Rome (Princeton, NJ, 1995).

Gundert 2002: B. Gundert, Soma and Psyche in Hippocratic Medicine [in J. Wright / P. Potter, eds.: Psyche and Soma: Physicians and Metaphysicians on the Mind-Body Problem from Antiquity to Enlightenment, Oxford], pp. ed., 13-35.

Halliwell 2008: S. Halliwell, Greek Laughter: A Study of Cultural Psychology from Homer to Early Christianity (Cambridge, 2008).

Harmon 1936: A. M. Harmon, Lucian, Vol. V, Loeb Classical Library (Cambridge, Mass., 1936).

Holford-Strevens 2003: L. Holford-Strevens, Aulus Gellius: An Antonine Scholar and his Achievement, Revised Edition (Oxford, 2003).

Howley 2018: J. Howley, Aulus Gellius and Roman Reading Culture (Cambridge, 2018).

Kaster 2005: R. Kaster, Emotion, Restraint and Community in Ancient Rome (Oxford, 2005).

Kazantzidis 2018: G. Kazantzidis, Between Insanity and Wisdom: Perceptions of Melancholy in the Ps.-Hippocratic Letters 10-17 [in C. Thumiger / P. N. Singer, eds.: Mental Illness in Ancient Medicine: From Celsus to Paul of Aegina, Leiden], pp.35-78.

Keulen 2009: W. H. Keulen, Gellius the Satirist: Roman Cultural Authority in Roman Nights (Leiden, 2009).

Kidd 2014: S. E. Kidd, Nonsense and Meaning in Ancient Greek Comedy (Cambridge, 2014). 
Kim 2017: L. Kim, Atticism and Asianism [in D. S. Richter / W. A. Johnson, eds.: The Oxford Handbook of the Second Sophistic, Oxford, 2017], pp. 41-66.

Klotz / Oikonomopoulou 2011: F. Klotz / K. Oikonomopoulou, Introduction [ in F. Klotz / K. Oikonomopoulou, eds.: The Philosopher's Banquet: Plutarch's Table Talk in the Intellectual Culture of the Roman Empire, Oxford], pp. 1-34.

Lateiner 2017: D. Lateiner, Evoking Disgust in the Latin Novels of Petronius and Apuleius [in D. Lateiner / D. Spatharas, eds.: The Ancient Emotion of Disgust, Oxford], pp. 203-34.

Martin, forthcoming: P. Martin, Cleansing the Palate: Vomit and Satire in Lucian's Lexiphanes [in G. Kazantzidis / N. Tsoumpra, eds.: Morbid Laughter: Exploring the Comic Dimensions of Disease in Classical Antiquity, ICS special issue, forthcoming].

Mattern 2013: S. P. Mattern, The Prince of Medicine: Galen in the Roman Empire (Oxford, 2013).

Padel 1995: R. Padel, Whom Gods Destroy: Elements of Greek and Tragic Madness (Princeton, NJ, 1995).

Pearcy 1984: L. T. Pearcy, Melancholy Rhetoricians and Melancholy Rhetoric: "Black Bile" as a Rhetorical and Medical Term in the Second Century A.D., Journal of the History of Medicine and Allied Sciences 39: 446-56.

Rimell 2002: V. Rimell, Petronius and the Anatomy of Fiction (Cambridge, 2002).

Sheffield 2006: F. Sheffield, Plato's Symposium: The Ethics of Desire (Oxford, 2006).

Storey 2003: I. C. Storey, Eupolis: Poet of Old Comedy (Oxford, 2003).

Strauss 1998: J. Strauss, Subjects of Terror: Nerval, Hegel and the Modern Self (Stanford, 1998).

Swain 2008: S. Swain, Social Stress and Political Pressure: On Melancholy in Context [in P. E. Pormann, ed.: Rufus of Ephesus: On Melancholy, Tübingen], pp. 113-38.

Thumiger 2017: C. Thumiger, A History of the Mind and Mental Health in Classical Greek Medical Thought (Cambridge, 2017).

Van der Eijk 2005: P. J. van der Eijk, Medicine and Philosophy in Classical Antiquity: Doctors and Philosophers on Nature, Soul, Health and Disease (Cambridge, 2005).

Van der Eijk 2008: P. J. van der Eijk, Rufus' On Melancholy and its Philosophical Background [in P. E. Pormann, ed.: Rufus of Ephesus: On Melancholy, Tübingen, 2008], pp. 159-78. 
Webster 2016: C. Webster, Voice Pathologies and the 'Hippocratic Triangle' [in G. Petridou / C. Thumiger, eds.: Homo Patiens: Approaches to the Patient in the Ancient World, Leiden], pp. 166-99.

Whitmarsh 2001: T. Whitmarsh, Greek Literature and the Roman Empire: The Politics of Imitation (Oxford, 2001).

Whitmarsh 2005: T. Whitmarsh, The Second Sophistic (Oxford, 2005).

Worman 2008: N. Worman, Abusive Mouths in Classical Athens (Cambridge, 2008). 